\title{
ARHGEF2 Gene
}

National Cancer Institute

\section{Source}

National Cancer Institute. ARHGEF2 Gene. NCI Thesaurus. Code C101780.

This gene is involved in the modulation of GT Pase signaling. 